\title{
Climate Change: Concerns, Beliefs and Emotions in Residents, Experts, Decision Makers, Tourists, and Tourist Industry
}

\author{
Igor Knez ${ }^{1}$, Sofia Thorsson ${ }^{2}$, Ingegärd Eliasson ${ }^{3}$ \\ ${ }^{1}$ Department of Social Work and Psychology, University of Gävle, Gävle, Sweden \\ ${ }^{2}$ Department of Earth Sciences, University of Gothenburg, Göteborg, Sweden \\ ${ }^{3}$ Department of Conservation, University of Gothenburg, Göteborg, Sweden \\ Email: igor.knez@hig.se, sofiat@gvc.gu.se, ingegard.eliasson@conservation.gu.se
}

Received March 18, 2013; revised April 16, 2013; accepted May 13, 2013

Copyright (C) 2013 Igor Knez et al. This is an open access article distributed under the Creative Commons Attribution License, which permits unrestricted use, distribution, and reproduction in any medium, provided the original work is properly cited.

\begin{abstract}
The aim was to investigate effects of different groups of individuals (residents, tourists, experts, decision makers and members of tourist industry) and demographic variables (gender, age, education) on climate change-related concerns, beliefs and emotions. In line with the predictions: 1) Experts were shown to be least concerned for and afraid of climate change impact; 2) Youngest participants were found to be most, and oldest least, concerned for their future; 3) Women were shown to be more concerned for and afraid of the consequences of climate change; and 4) Men and the least educated participants believed their jobs to be more threatened by the environmental laws and protection, and the latter ones believed moreover that the claims about climate change are exaggerated. Implications of these findings for value orientations and their relationships to environmental concerns, beliefs and emotions are discussed.
\end{abstract}

Keywords: Climate Change; Demographic Variables; Concerns; Beliefs; Emotions

\section{Introduction}

Climate change is a continuing present day issue. News about floods, heat waves and storms and their impact on society reach us almost every day. These reports imply a threat to our present way of living, urging for responsebility, pro-environmental behaviour and ecologically sustainable progress. There is an increasing awareness that climate change is not only an ecological and economic dilemma, but also a social and psychological one [1-3], meaning that drastic policies are necessary to prevent a serious lack of natural resources by promoting a sustainable behaviour [4].

It is difficult to conceptualize and frame the climate change problem as well as to temporally and psychologically foresee its consequences, meaning that human processes of climate change related perception are for the most part uncertain $[5,6]$. Due to the embedded conflict between an individual level of short-term self-interest (e.g. accumulating damaging gases by driving the car a lot) and long-term collectivistic natural resource management (to decrease urban air pollution), the climate change issues can also be conceptualized as resource dilemmas, involving a conflict between individual and collective interests [7].

Climate change and its consequences are disseminated to the general public by the media, scientists and politicians [8]; information that can be vague, is often "scientifically uncertain" [9], and is due to this misunderstanding [10]. This relation between knowledge of climate change per se and confidence in that knowledge on an individual level has recently been found to vary across types of people [11], showing that both knowledge and confidence in one's own knowledge were highest among scientists followed by journalists, politicians and laypersons. It is also indicated that better knowledge of $[4,12]$, and greater concern for $[13,14]$, climate change may promote pro-environmental behaviour.

In accordance with the work of Schwartz $[15,16]$ on structure and contents of human values, Stern and colleagues [17-21] and Schultz and colleagues [22-26] have extended this account to comprise environmental-related concerns (affect associated with environmental issues), attitudes (beliefs, values and behavioural intentions asso- 
ciated with environmental issues) and worldviews (our relationships to environment). More precisely, it is assumed that awareness of climate change has an impact on:

Oneself (belief about consequences “for oneself') is grounded on the person's egoistic value orientation (comprising dimensions of power, social power, authority and wealth vs. achievement, ambition, capability, success, influence);

Others (belief about consequences "for others") are grounded on the person's benevolence value orientation (comprising dimensions of being helpful, forgiving, loyal, responsible);

Biosphere (belief about consequences "for biosphere") is grounded on the person's universalism value orientation (comprising dimensions of broad-mindedness, equality, social justice, a world of peace).

Each of the beliefs about consequences for oneself, others and the biosphere is assumed to correlate positively with each of the environment-related concerns for: 1) "myself, my lifestyle, my health, my future"; 2) "all people, people in my country, children, my children"; and 3) "plants, marine life, birds, animals" respectively; see also [27,28]. Hansla et al [29] however, have, pointed out that the relationship between environmental-related values, beliefs and concerns may vary across different groups of individuals. In addition, Olofsson \& Öhman [30] have indicated that demographic variables such as age, gender, education, political affiliation and location may influence people's environmental concerns; see also [17,31,32].

It has also been shown that people experience and express different types of emotion, such as worry and hope, related to global environmental problems [33]. For example, Garcia-Mira et al. [34] have indicated that we may estimate local (e.g. increased number of cars) compared to global (e.g. increased pollution of atmosphere) environmental problems as less worrying; and Ojala [35] reported that an emotional reaction/expression of worriment may vary with gender, indicating that women embrace environmental-related altruistic values to a higher degree than do men.

\section{Present Study}

Consequences of climate change on tourism are in particular difficult to predict [36-38]. This societal and economic sector will, in general terms, be deeply affected, because tourism by definition is related to climate and weather [39-43]. It is, for example, suggested that warmer summers may decrease tourism in the Mediterranean region [44], but expand it in the Northern and Western Europe [45], as well as enhance and develop spring and fall tourism in Southern Europe [44].

Despite the fact that tourism as a phenomenon consti- tutes a considerable part of the global economy and that tourist streams may be radically modified in step with the climate change $[46,47]$, there still appears to be a lack of responsiveness and commitment among politicians, stakeholders and the tourist industry [48-50].

Based on the findings reviewed above the aim was to investigate effects of different groups of individuals (residents, tourists, experts, decision makers and members of tourist industry) and demographic variables (gender, age and education) on participants' climate-change-related concerns, beliefs and emotions, including the following two hypotheses:

Hypothesis 1. In line with some previous findings which suggest differences in environment-related socio-psychological constructs between different groups of individuals [8-11,29,49,51], the present study included participants from five types of group (residents, tourists, experts, decision makers and members of the tourist industry) defining the independent variable of Type of Group. The hypothesis was that the impact of climate change measured as environmental-related concerns, beliefs ("awareness" of the climate change impact), and emotions would vary across these groups of individuals, due to differences in their underlying environmental issue-related value orientations [18,21,52].

Hypothesis 2. In addition to Hypothesis 1 and across the Type of Group variable, a second analysis included demographic (independent) variables of Gender, Age and Education previously indicated to influence environmental concerns [30-32,53-55] and emotions [33,35,56]. The hypothesis was that older vs. younger, men vs. women, and participants with lower vs. higher education would show less environment-related concerns and beliefs; and that men would be found to be less worried about climate change.

\section{Method}

\subsection{Study Area and Climate}

The city of Gothenburg (Göteborg, Sweden, $57^{\circ} 42^{\prime} \mathrm{N}$, $11^{\circ} 58^{\prime} \mathrm{E}$ - with a population of approx. 500,000, approx. 900,000 in the region). Being located on the west coast of Sweden, Gothenburg is one of the country's warmest cities thanks to the Gulf Stream and its warming waters. Summers are predictably warm, with an average maximum daily air temperature from June to August of about $20^{\circ} \mathrm{C} / 68^{\circ} \mathrm{F}$ or more. Summer evenings in Gothenburg are warm and balmy at times, with night-time temperatures rarely falling below $13^{\circ} \mathrm{C} / 55^{\circ} \mathrm{F}$.

\subsection{Sample}

A total of 1000 households located within the City of Gothenburg were sent a "climate survey" during the sum- 
mer 2009. They were randomly identified from a population register. The questionnaire was also handed out at different tourist locations to 1000 tourists visiting the town in June to August 2009. The survey was also sent to 30 experts (scientists working with climate and environment issues); 67 decision makers (politicians, stakeholders); and 156 members of the tourist industry (hotels, museums, theatres, amusement parks, hauliers, conference centres, event companies, etc.). The survey comprised a number of sections including questions about demographic variables, climate, climate change-related behaviours and attitudes, etc. Data on climate change-related concerns, beliefs and emotions will be reported in the present study.

Procedures and response rates. After two contacts (After one week a reminder was sent to all those that had not answered. A week later a second reminder was sent.) 1257 responses were achieved, distributed across five groups of participants: Residents (528); Tourists (576); Experts (18); Decision Makers (33); and Tourist Industry (102).

Tourists. According to the World Tourism Organisation (UNWTO, 2008), a tourist is either a person who for pleasure has travelled at least $100 \mathrm{~km}$. from their domicile, for a stay of at least 24 hours, or a person who for various reasons (e.g. pleasure, shopping, official journey) has left their domicile for another place. In the present study a definition of a tourist was a person living outside the Gothenburg region (comprising 13 municipalities) visiting Gothenburg city for pleasure and/or other reasons. For each tourist who agreed to participate, name, e-mail and telephone number were documented. Each person was given a questionnaire (in English, Germany or Swedish), stamped and addressed reply envelope, and an e-mail login code. The majority $(75 \%)$ of tourists came from northern Europe (Sweden, Norway, Finland, and Denmark), 20\% from other European countries and 5\% from outside Europe. This is in accordance with local tourist statistics (from the Swedish Agency for Economic and Regional Growth) for accommodation showing that domestic tourists dominate.

\subsection{Measures}

Concerns. Climate change-related concerns [29] were measured with 12 self-report items responding to the statement, "I am concerned about climate change because of the consequences for: myself, my lifestyle, my health, my future, all people, people in my country, children, my children, plants, marine life, birds, other animals." Responses were made using a 7-point Likert scale ranging from 1 (completely disagree) to 7 (completely agree).

Beliefs. Climate change-related beliefs [29] were meas- ured with 6 self-report statements: 1) Laws that protect the environment limit my choices and personal freedom; 2) Protecting the environment will threaten jobs for people like me; 3) Effects of climate change on public health are worse than people realize; 4) Pollution generated in one country harms people all over the world; 5) Over the next several decades, thousands of species will vanish; 6) Claims that there is climate change are exaggerated. Participants were asked to respond to these statements on a 7-point Likert scale ranging from 1 (completely disagree) to 7 (completely agree).

Emotions. Affect states related to climate change [57] were measured with 4 self-report items answering the questions of: 1) How hopeful do you feel about the place where you live (Item 1) and the world (Item 2) respectively when you think about climate change risks? and 2) How afraid do you feel about the place where you live 1) and the world 2) respectively when you think about climate change risks? Participants were asked to respond to these questions on a 7-point Likert scale ranging from 1 (not at all) to 7 (very much).

\subsection{Design}

A non-equivalent, comparison-group, quasi-experimental design [58] was used. Compared with a "true experiment" [59], this means that inferences drawn about the causal relationships between independent and dependent variables are considered to be weaker.

Independent variables. Five groups of participants: Residents, Tourists, Experts, Decision Makers, Tourist Industry. These were the independent variables involved in "Analyses 1" (see Result section below). In "Analysis 2", the independent variables of Gender (males vs. females; 590, 578 participants per category), Age (-25, 26 - 35, 36 - 45, 46 - 55, 56 - 65, 66+; 147, 211, 256, 233, 208, 193 participants per category) and Education (Primary, High School or equivalent, Bachelor's Degree, Master's Degree, Doctoral Degree; 140, 542, 285, 203, 52 participants per category) across the five groups of participants were used as the independent variables (see Result below).

Dependent variables. 22 items (statements, questions) distributed across three measures of climate change-related concerns (12 items), beliefs (6 items) and emotions (4 items).

\section{Results}

All data were subjected to MANOVAs (multivariate analyses of variance) due to the several items involved in each dependent variable. This section is divided into two main types of analyses: 1) "Effects of five groups of participants"; and 2) "Effects of gender, age and education" (demographic variables across the five groups). Accord- 
ingly, the first type of analyses involved one independent variable, that of Type of Group (related to Hypothesis 1, see Introduction), and the second type of analyses involved three independent variables, that of Gender, Age and Education (related to Hypothesis 2, see Introduction).

\subsection{Effects of Five Groups of Participants}

Concerns. A main significant effect of Type of Group was obtained, Wilk's Lambda $=0.89, F(48,3892)=2.49$, $p<0.001$, associated with all 12 statements $(p$ values $<$ from 0.05 to 0.01). As can be seen in Figure 1, the grand mean for the concerns across the five groups of participants varied between values of 3.55 (I am concerned about climate change because of the consequences for my lifestyle) and 5.53 (I am concerned about climate change because of the consequences for children) showing that participants in general were least concerned about the consequences for their lifestyle and most for future generations, $t(1061)=27.99, p<0.01$.
According to Figure 2 and in general terms, Experts (similarly with Decision Makers and Tourist Industry) were shown to be least, and Tourists most, concerned for the consequences of climate change, $t(582)=2.11, p<$ 0.05 .

Beliefs. A main significant effect of Type of Group was obtained, Wilk's Lambda $=0.95, F(24,3988)=2.56$, $p<0.01$, associated with the statements of: 1) The effects of climate change on public health are worse than people realize $(p=0.06) ; 2)$ Pollution generated in one country harms people all over the world $(p<0.01)$; and 3) Claims that there is climate change are exaggerated $(p<0.01)$.

As can be seen in Table 1, Tourists were the group that most believed that the effects of climate change on public health are worse than people realize and that pollution generated in one country harms people all over the world. In addition, Residents considered the claims about consequences of a climate change as more exaggerated than did the other four groups.

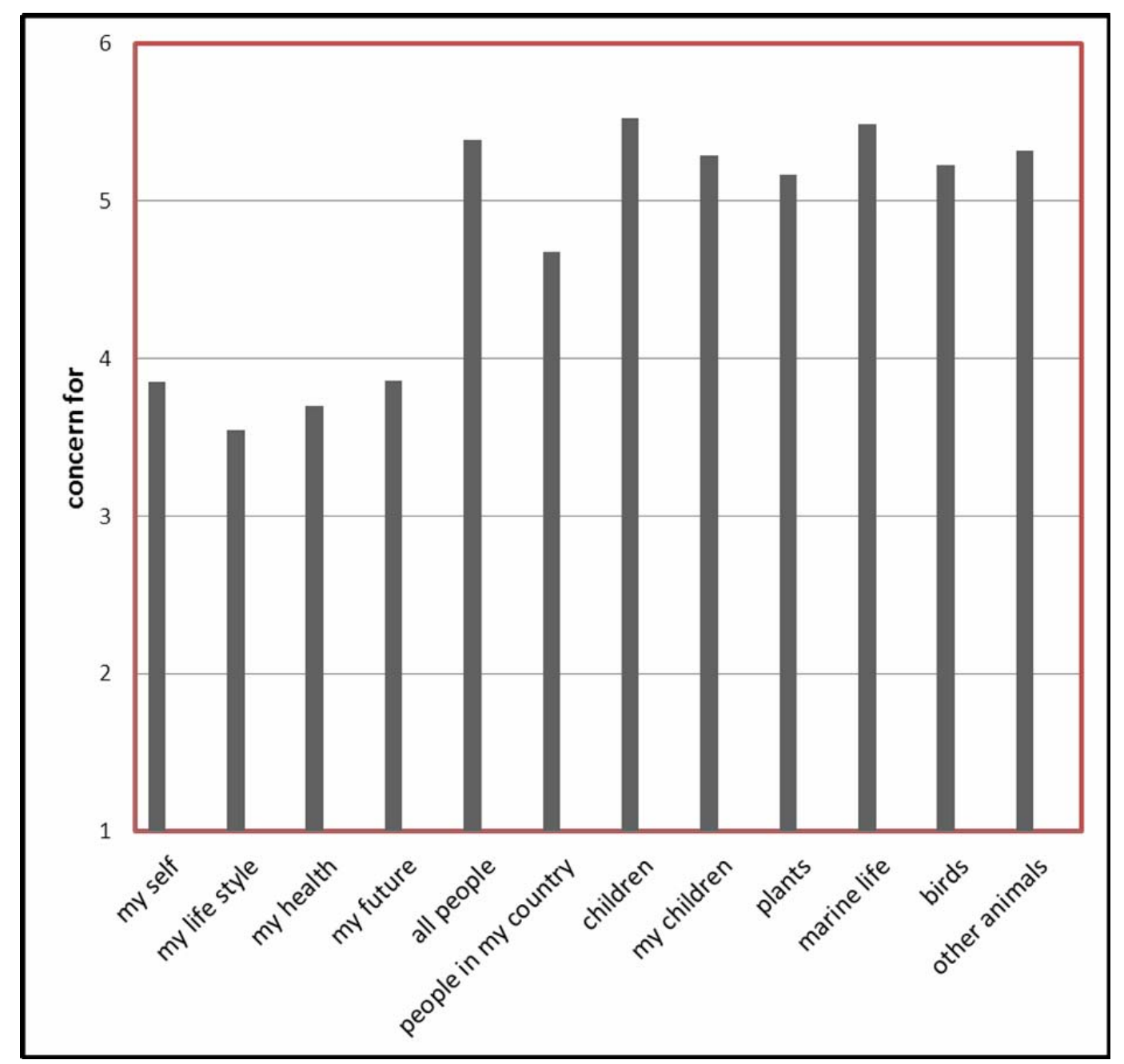

Figure 1. Mean concern for type of concern (concerns for: myself, my lifestyle, my health, my future, all people, people in my country, children, my children, plants, marine life, birds, other animals) across five groups of participants. 


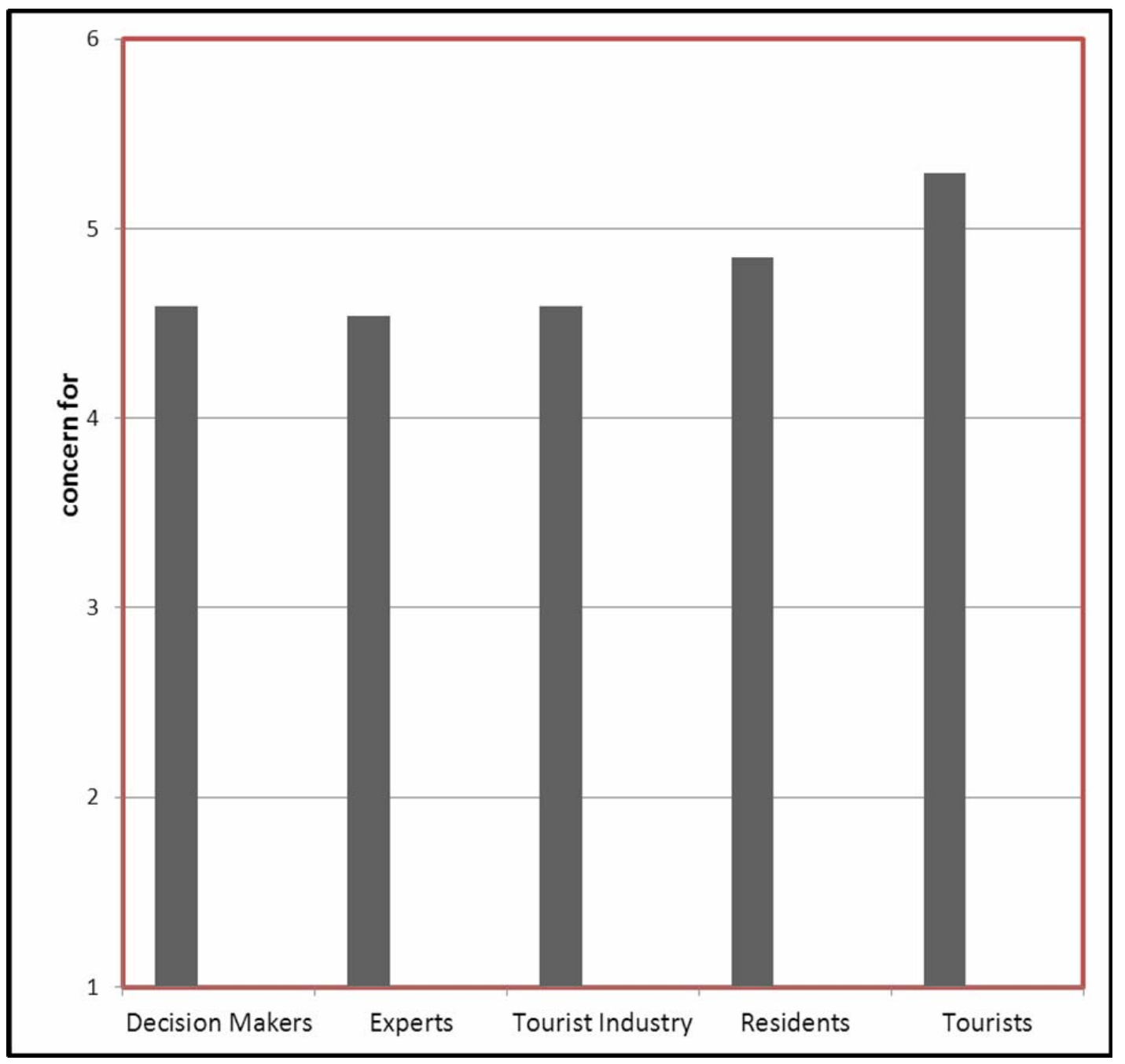

Figure 2. Mean concern (across type of concern) for Type of Group (Decision Makers, Experts, Tourist Industry, Residents, Tourists).

Furthermore, all participants (independently of group) believed for the most part that pollution generated in one country harms people all over the world and least that protecting the environment will threaten jobs for people like them (see Figure 3), $t(1185)=58.71, p<0.01$.

Emotions. A main significant effect of Type of Group was obtained, Wilk's Lambda $=0.93, F(16,3507)=5,11$, $p<0.001$, associated with the questions: 1) How hopeful do you feel when you think about climate change risks, in the world? $(p<0.01)$; and How afraid do you feel when you think about climate change risks, where you live 2 ) and in the world (3)? ( $p$ values $<0.01$ ). The former showed Residents as most, and Decision Makers as least, hopeful (see Table 2) and the latter indicated that Residents and Tourists feared most, and Decision Makers and Experts feared least, climate change consequences for the place where they lived. Tourists feared most and Experts least the impact of climate change for the whole world (see Table 3).
However, and in general, all participants (independently of the group) were found to be most hopeful for the environment where they live compared to the whole world and, consistently, more afraid for the whole world than for their neighboring environment concerning climate change consequences (see Figure 4).

\subsection{Effects of Gender, Age and Education}

Concerns. Main significant effects of Age, Wilk's Lambda $=0.90, F(60,4054)=1.49, p<0.01$, and Education, Wilk's Lambda $=0.92, F(48,3334)=1.55, p<$ 0.01 , were shown. The first effect was associated with the concerns for my future $(p<0.01)$ and the second with the concerns for my lifestyle $(p<0.01)$ and my health $(p$ $<0.05$ ). A tendency towards a main significant effect of Gender was also indicated, Wilk's Lambda $=0.98, F(12$, $865)=1.52, p=0.11$, significantly associated with all 12 statements ( $p$ values $<$ from 0.05 to 0.01 ). 
Table 1. Post hoc, multiple comparisons (LSD, least significant difference) between the type of group (Decision Makers, DM; Experts, E; Tourist Industry, TI; Residents, R; Tourists, T) associated with the statements of (1) Effects of climate change on public health are worse than people realize; (2) Pollution generated in one country harms people all over the world; and (3) Claims that there is a climate change are exaggerated. Only significant differences are reported with statistics of mean difference (M.D.), standard error (S.E.), $p$ value and lower and upper bound of $95 \%$ confidence interval (L.B. and U.B.).

\begin{tabular}{ccccccc}
\hline Statements & Groups & M.D. & S.E. & $p$ & L.B. & U.B. \\
\hline Effects... & R vs. T & -0.30 & 0.11 & 0.01 & -0.51 & -0.09 \\
Pollution... & R vs. T & -0.29 & 0.09 & 0.00 & -0.47 & -0.09 \\
Claims.. & DM vs. R & -0.87 & 0.34 & 0.01 & -1.54 & -0.21 \\
& E vs. R & -0.92 & 0.46 & 0.05 & -1.83 & -0.02 \\
& TI vs. R & -0.78 & 0.20 & 0.00 & -1.17 & -0.39 \\
& R vs. T & 0.51 & 0.11 & 0.00 & -0.29 & 0.73 \\
\hline
\end{tabular}

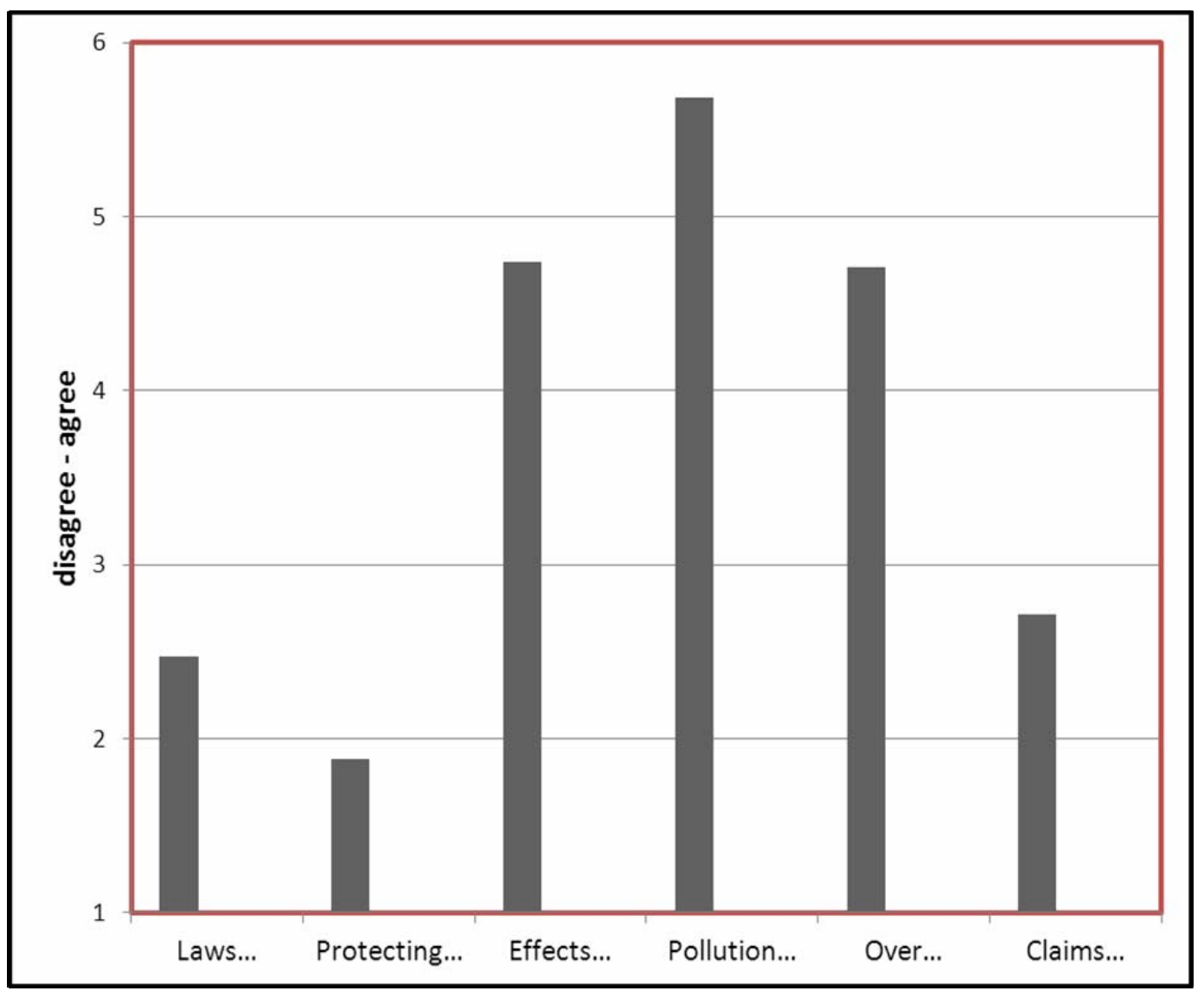

Figure 3. Mean disagreement-agreement across five groups of participants associated with statements of (1) Laws that protect the environment limit my choices and personal freedom; (2) Protecting the environment will threat jobs for people like me; (3) Effects of climate change on public health are worse than people realize; (4) Pollution generated in one country harms people all over the world; (5) Over the next several decades, thousands of species will vanish; (6) Claims that there is a climate change is exaggerated.

Table 2. Post hoc, multiple comparisons (LSD, least significant difference) between the Type of Group (Decision Makers, DM; Experts, E; Tourist Industry, TI; Residents, R; Tourists, T) associated with the question of "How much do you feel hopeful for the world when you think about the climate change risks?" Only significant differences are reported with statistics of mean difference (M.D.), standard error (S.E.), p value and lower and upper bound of $95 \%$ confidence interval (L.B. and U.B.)

\begin{tabular}{ccccccc}
\hline Question & Groups & M.D. & S.E. & $p$ & L.B. & U.B. \\
\hline Hope for the world & DM vs. R & -0.66 & 0.28 & 0.02 & -1.21 & -0.11 \\
& TI vs. R & -0.42 & 0.17 & 0.02 & -0.76 & -0.08 \\
& R vs. T & 0.40 & 0.09 & 0.00 & 0.21 & 0.58 \\
\hline
\end{tabular}


Table 3. Post hoc, multiple comparisons (LSD, least significant difference) between the Type of Group (Decision Makers, DM; Experts, E; Tourist Industry, TI; Residents, R; Tourists, T) associated with the questions of "How much do you feel fear for place where you live and the world respectively when you think about the climate change risks?" Only significant differences are reported with statistics of mean difference (M.D.), standard error (S.E.), $p$ value and lower and upper bound of $95 \%$ confidence interval (L.B. and U.B.)

\begin{tabular}{|c|c|c|c|c|c|c|}
\hline Questions & Groups & M.D. & S.E. & $p$ & L.B. & U.B. \\
\hline \multirow[t]{5}{*}{ Fear for place where I live } & DM vs. R & 0.81 & 0.31 & 0.01 & -1.42 & -0.21 \\
\hline & DM vs. T & -1.00 & 0.31 & 0.00 & -1.60 & -0.40 \\
\hline & E vs. R & -0.87 & 0.44 & 0.05 & -1.74 & -0.01 \\
\hline & E vs. T & -1.06 & 0.44 & 0.02 & -1.93 & -0.20 \\
\hline & TI vs. $\mathrm{R}$ & -0.54 & 0.19 & 0.01 & -0.91 & -0.16 \\
\hline \multirow[t]{4}{*}{ Fear for the world } & DM vs. T & -0.79 & 0.33 & 0.02 & -1.44 & -0.13 \\
\hline & E vs. T & -1.25 & 0.48 & 0.01 & -2.19 & -0.30 \\
\hline & TI vs. T & -0.74 & 0.21 & 0.00 & -1.14 & -0.34 \\
\hline & R vs. T & -0.64 & 0.11 & 0.00 & -0.86 & -0.42 \\
\hline
\end{tabular}

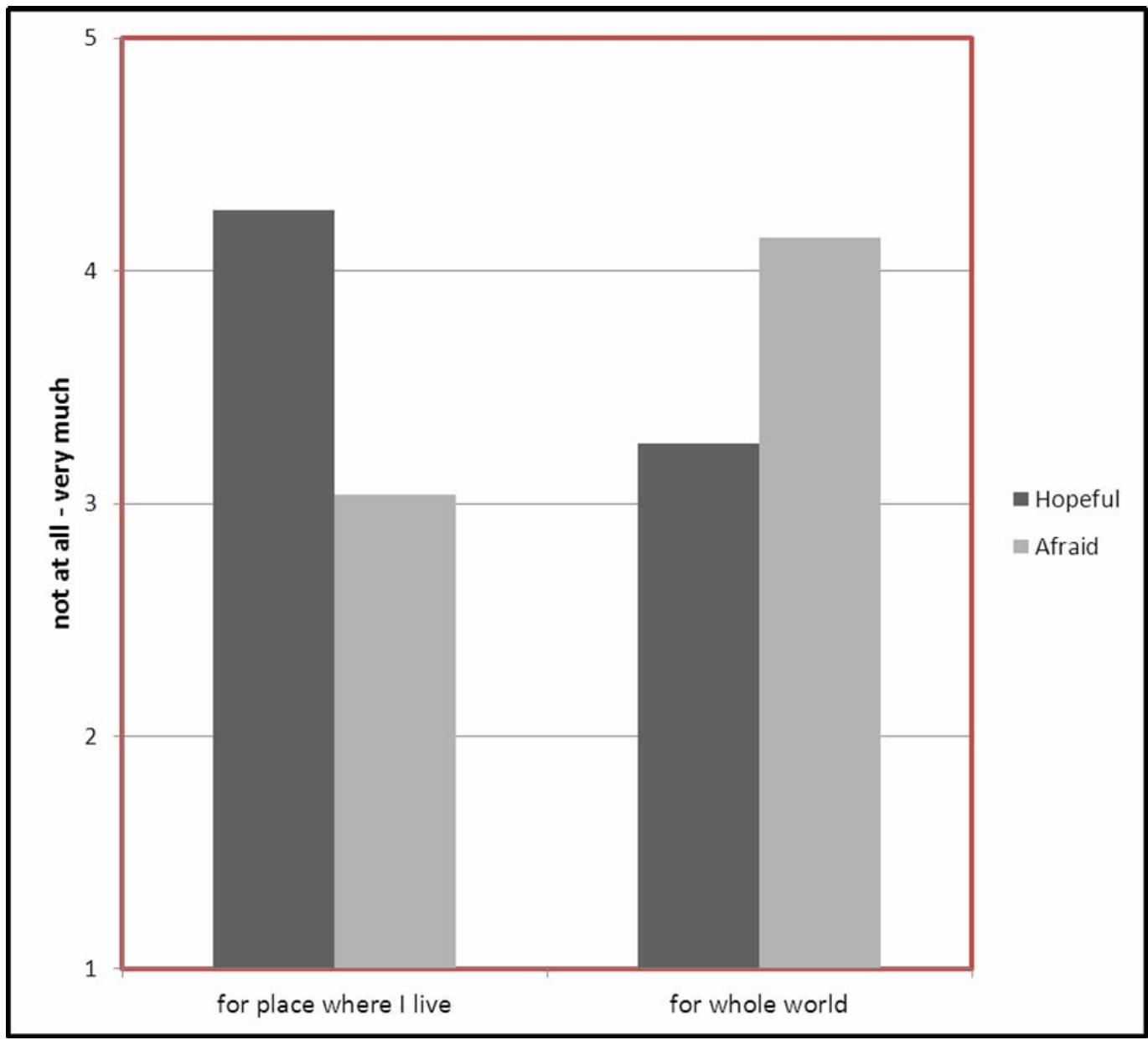

Figure 4. Mean hope (Hopeful) and fear (Afraid) for two types of environments (neighborhood vs. whole world) across five groups of participants.

As can be seen in Table 4, the youngest participants (25 years) were most, and the oldest (65+ years) participants least, concerned about their future as related to climate change consequences.
Women were shown to be generally (all 12 statements) more concerned for the effects of climate change (see Figure 5). Furthermore, and as can be seen in Table 5, the least educated participants were mostly concerned 
Table 4. Post hoc, multiple comparisons (LSD, least significant difference) between the Age groups (-25, 26 - 35, 36 - 45, 46 $55,56-65,66+)$ and concern for my future. Only significant differences are reported with statistics of mean difference (M.D.), standard error (S.E.), p value and lower and upper bound of $95 \%$ confidence interval (L.B. and U.B.).

\begin{tabular}{|c|c|c|c|c|c|c|}
\hline Concern for & Age group & M.D. & S.E. & $p$ & L.B. & U.B. \\
\hline \multirow[t]{9}{*}{ My future } & -25 vs. $26-35$ & 0.43 & 0.22 & 0.05 & 0.00 & 0.86 \\
\hline & -25 vs. $36-45$ & 0.65 & 0.21 & 0.00 & 0.24 & 1.07 \\
\hline & -25 vs. $46-55$ & 0.83 & 0.22 & 0.00 & 0.41 & 1.26 \\
\hline & -25 vs. $56-65$ & 0.88 & 0.23 & 0.00 & 0.43 & 1.34 \\
\hline & -25 vs. $66+$ & 1.21 & 0.26 & 0.00 & 0.71 & 1.71 \\
\hline & $26-35$ vs. $46-55$ & 0.40 & 0.19 & 0.04 & 0.01 & 0.79 \\
\hline & $26-35$ vs. $56-65$ & 0.45 & 0.20 & 0.03 & 0.04 & 0.87 \\
\hline & 26 - 35 vs. $66+$ & 0.77 & 0.21 & 0.00 & 0.31 & 1.24 \\
\hline & $36-45$ vs. $66+$ & 0.55 & 0.23 & 0.02 & 0.09 & 1.01 \\
\hline
\end{tabular}

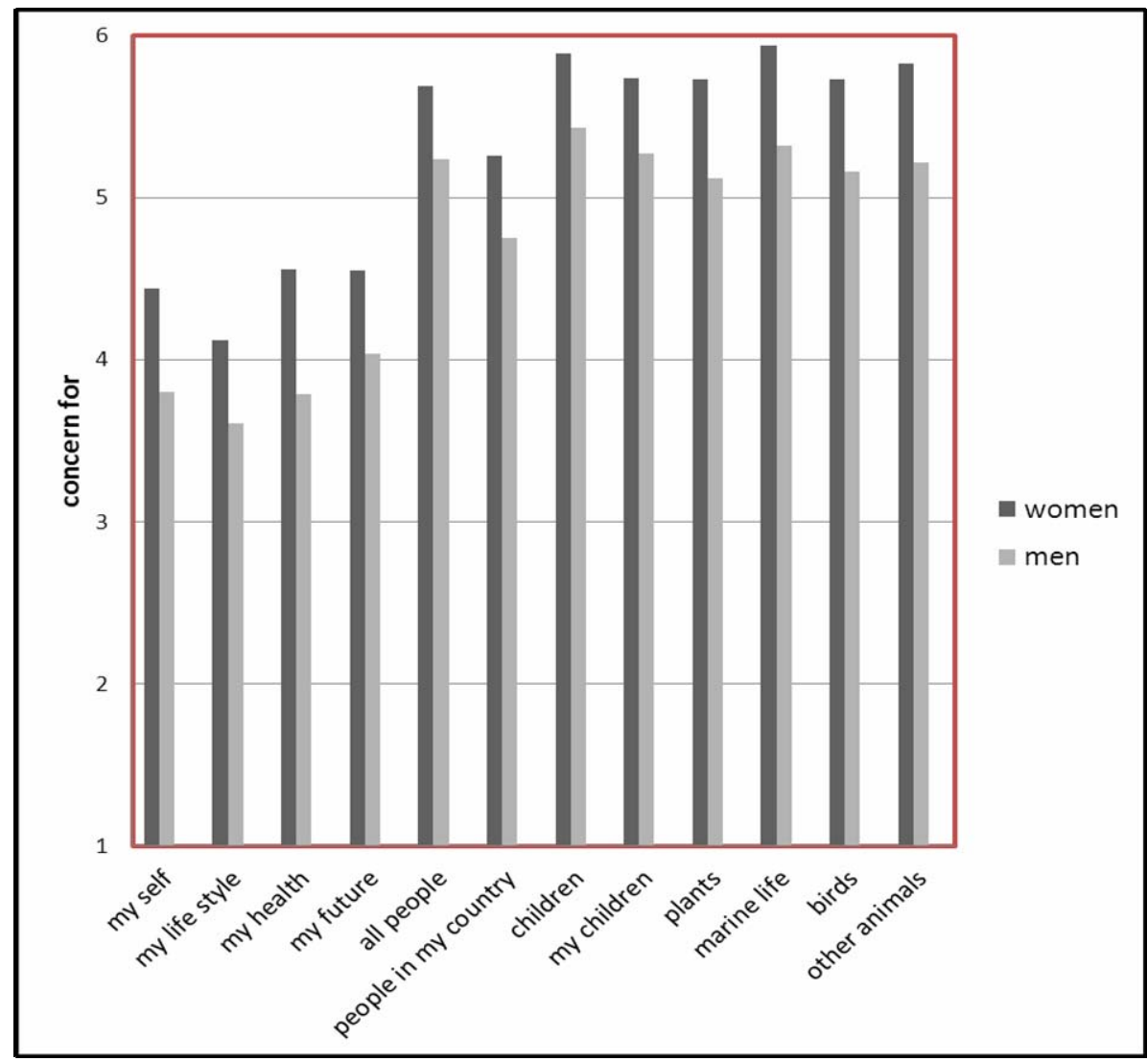

Figure 5. Mean concern in women and men for type of concern.

Table 5. Post hoc, multiple comparisons (LSD, least significant difference) between the Education Level groups (Primary Education, PE, High School, HS, Bachelor Degree, BD, Master Degree, MD, Doctoral Degree, DD) and concerns for my lifestyle and health. Only significant differences are reported with statistics of mean difference (M.D.), standard error (S.E.), $p$ value and lower and upper bound of $95 \%$ confidence interval (L.B. and U.B.).

\begin{tabular}{|c|c|c|c|c|c|c|}
\hline Concern for & Education level & M.D. & S.E. & $p$ & L.B. & U.B. \\
\hline \multirow[t]{4}{*}{ My lifestyle } & PE vs. HS & 0.90 & 0.23 & 0.00 & 0.44 & 1.35 \\
\hline & PE vs. BD & 1.18 & 0.25 & 0.00 & 0.69 & 1.66 \\
\hline & PE vs. MD & 1.05 & 0.26 & 0.00 & 0.55 & 1.56 \\
\hline & PE vs. DD & 0.74 & 0.35 & 0.04 & 0.05 & 1.43 \\
\hline \multirow[t]{5}{*}{ My health } & PE vs. HS & 0.96 & 0.24 & 0.00 & 0.49 & 1.43 \\
\hline & PE vs. BD & 1.06 & 0.25 & 0.00 & 0.56 & 1.55 \\
\hline & PE vs. MD & 1.11 & 0.26 & 0.00 & 0.62 & 1.66 \\
\hline & HS vs. DD & 0.75 & 0.30 & 0.01 & 0.16 & 1.34 \\
\hline & BD vs. DD & 0.66 & 0.31 & 0.04 & 0.05 & 1.27 \\
\hline
\end{tabular}


about their lifestyle and health.

Beliefs. Main significant effects of Age, Wilk's Lambda $=0.95, F(30,3946)=1.88, p<0.01$, Gender, Wilk's Lambda $=0.96, F(6,986)=4.26, p<0.01$, and Education, Wilk's Lambda $=0.94, F(24,3440)=2.47, p<0.01$, were shown.

The first effect was associated with the statements: 1) Pollution generated in one country harms people all over the world $(p=0.01)$; and 2) Claims that there is a climate change is exaggerated $(p=0.01)$, showing that participants aged 35 - 55 agreed mostly with statement 1 ) and the oldest ones (aged $66+$ ) agreed mostly with statement 2 ).
See Table 6 for comparisons between the Age groups.

As can be seen in Figure 6, the second effect was associated with the statements of: 1) Laws that protect the environment limit my choices and personal freedom $(p<$ $0.01)$; 2) Protecting the environment will threaten jobs for people like me $(p<0.01)$; 3$)$ Effects of climate change on public health are worse than people realize $(p<0.05)$. That is, compared to women, men were shown to estimate their freedom and jobs to be more threatened by environmental laws and protection. In addition, women estimated the effects of climate change on health as worse.

Table 6. Post hoc, multiple comparisons (LSD, least significant difference) between the Age groups ( $-25,26-35,36-45,46-$ 55, $56-65,66+)$ associated with the statements of: (1) Pollution generated in one country harms people all over the world; and (2) Claims that there is a climate change are exaggerated. Only significant differences are reported with statistics of mean difference (M.D.), standard error (S.E.), $p$ value and lower and upper bound of $95 \%$ confidence interval (L.B. and U.B.).

\begin{tabular}{|c|c|c|c|c|c|c|}
\hline Statements & Age group & M.D. & S.E. & $p$ & L.B. & U.B. \\
\hline \multirow[t]{4}{*}{ Pollution... } & $36-45$ vs. $56-65$ & 0.40 & 0.14 & 0.01 & 0.12 & 0.67 \\
\hline & 36 - 45 vs. $66+$ & 0.40 & 0.15 & 0.03 & 0.11 & 0.69 \\
\hline & $46-55$ vs. $56-65$ & 0.32 & 0.14 & 0.03 & 0.04 & 0.60 \\
\hline & 46 - 55 vs. $66+$ & 0.32 & 0.15 & 0.04 & 0.02 & 0.62 \\
\hline \multirow[t]{4}{*}{ Claims... } & -25 vs. $66+$ & -1.03 & 0.21 & 0.00 & -1.45 & -0.62 \\
\hline & $26-35$ vs. $46-55$ & -1.07 & 0.20 & 0.04 & -1.45 & -0.69 \\
\hline & $26-35$ vs. $56-65$ & -1.08 & 0.19 & 0.03 & -1.45 & -0.71 \\
\hline & $36-45$ vs. $66+$ & 0.75 & 0.20 & 0.02 & -1.14 & -0.35 \\
\hline
\end{tabular}

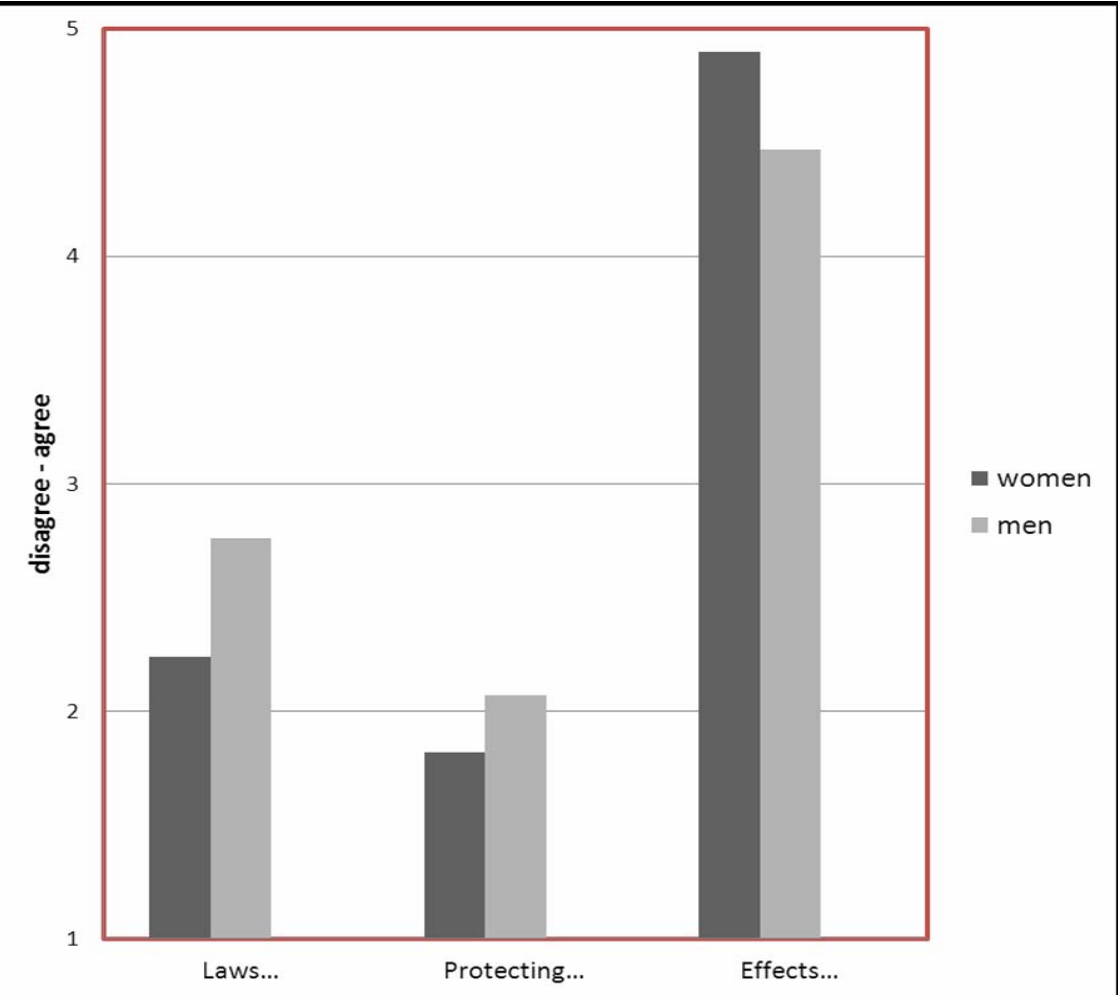

Figure 6. Mean disagreement-agreement in women and men associated with statements of (1) Laws that protect the environment limit my choices and personal freedom; (2) Protecting the environment will threat jobs for people like me; (3) Effects of climate change on public health are worse than people realize. 
The third effect was associated with the statements: 1) Protecting the environment will threaten jobs for people like me $(p<0.01)$; 2) Claims that there is climate change are exaggerated $(p<0.05)$. Compared to the other Education groups, the least educated participants considered their jobs to be more threatened by environmental protection and thought that the claims about climate change were exaggerated (see Table 7). In addition, and as can be seen in Figure 7, a tendency of decreasing agreement with educational level was indicated.

Table 7. Post hoc, multiple comparisons (LSD, least significant difference) between the Education Level groups (Primary Education, PE, High School, HS, Bachelor Degree, BD, Master Degree, MD, Doctoral Degree, DD) associated with the statements of: (1) Pollution generated in one country harms people all over the world; and (2) Claims that there is a climate change are exaggerated. Only significant differences are reported with statistics of mean difference (M.D.), standard error (S.E.), $p$ value and lower and upper bound of $95 \%$ confidence interval (L.B. and U.B.)

\begin{tabular}{|c|c|c|c|c|c|c|}
\hline Statements & Education level & M.D. & S.E. & $p$ & L.B. & U.B. \\
\hline \multirow[t]{5}{*}{ Protecting... } & PE vs. HS & 0.39 & 0.17 & 0.02 & 0.07 & 0.72 \\
\hline & PE vs. BD & 0.86 & 0.18 & 0.00 & 0.51 & 1.21 \\
\hline & PE vs. DD & 1.08 & 0.26 & 0.00 & 0.56 & 1.60 \\
\hline & HS vs. BD & 0.47 & 0.12 & 0.00 & 0.24 & 0.70 \\
\hline & HS vs. DD & 0.69 & 0.23 & 0.00 & 0.24 & 1.13 \\
\hline \multirow[t]{5}{*}{ Claims... } & PE vs. HS & 0.70 & 0.19 & 0.00 & 0.32 & 1.07 \\
\hline & PE vs. BD & 1.03 & 0.21 & 0.00 & 0.63 & 1.43 \\
\hline & PE vs. MD & 0.96 & 0.22 & 0.00 & 0.54 & 1.38 \\
\hline & PE vs. DD & 1.33 & 0.30 & 0.00 & 0.74 & 1.93 \\
\hline & HS vs. BD & 0.34 & 0.14 & 0.01 & 0.07 & 0.60 \\
\hline
\end{tabular}

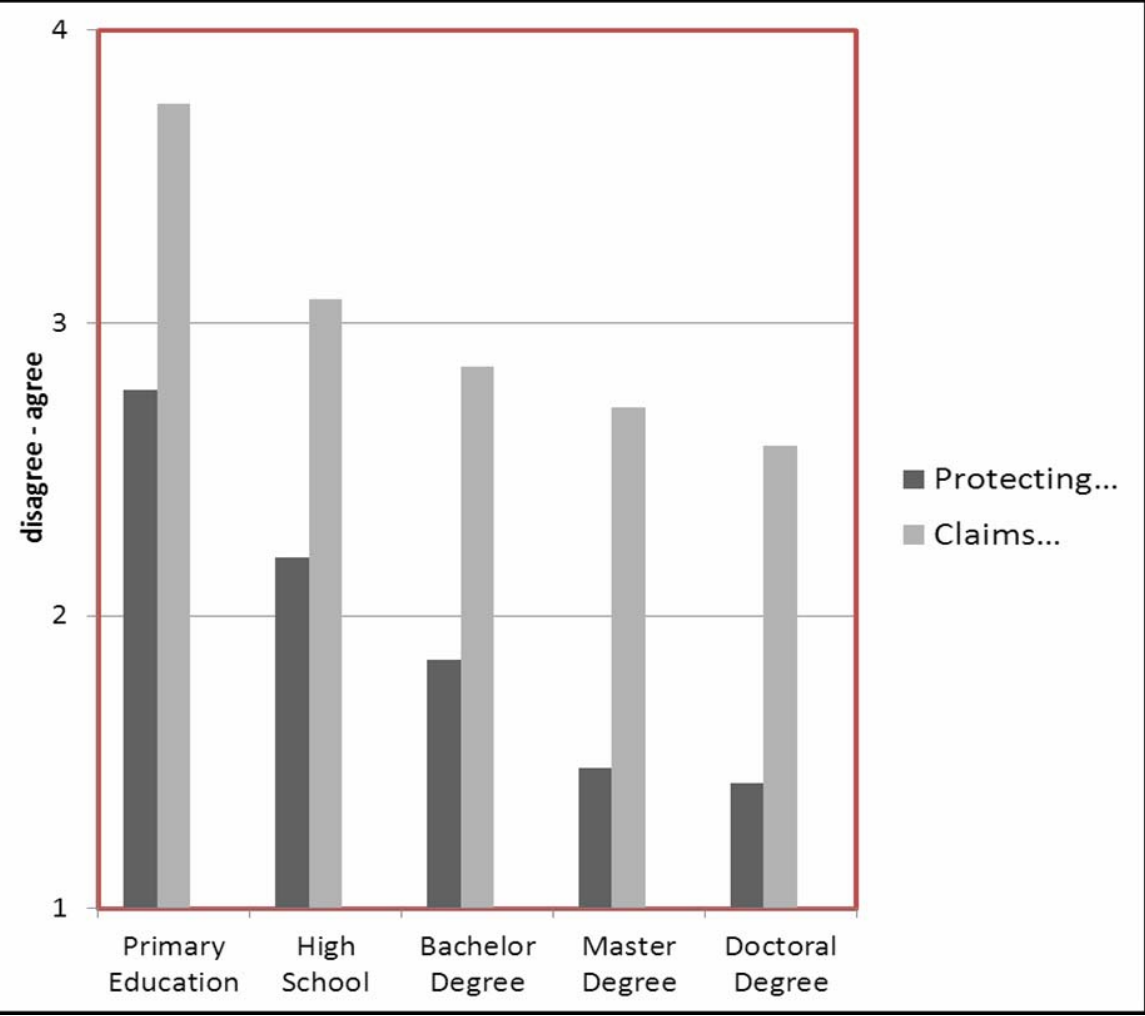

Figure 7. Mean disagreement-agreement in Education groups (Primary Education, High School, Bachelor Degree, Master Degree, Doctoral Degree) associated with statements of: (1) Protecting the environment will threat jobs for people like me; (2) Claims that there is climate change are exaggerated. 
Emotions. Main significant effects of Age, Wilk's Lambda $=0.96, F(20,3281)=2.09, p<0.01$, Gender, Wilk's Lambda $=0.99, F(4,989)=2.36, p<0.05$, and Education, Wilk's Lambda $=0.97, F(16,3950)=1.89, p$ $<0.05$, were shown.

As can be seen in Table 8, oldest and youngest participants were least hopeful about their neighbouring environment $(p<0.05)$, and youngest participants were most afraid for the whole world $(p<0.05)$ as related to climate change consequences.
Women were shown to be more afraid of climate change impact as related to both neighbouring environment $(p<$ $0.05)$ and the whole world $(p<0.01)$ than men (see Figure 8). Concerning the Education effect, no significant association with any particular question was shown, but a general tendency across all four questions indicated more fear than hope about the consequences of climate change. However, and as can be seen in Figure 9, participants with the lowest educational level were shown to be the least hopeful and the most afraid.

Table 8. Post hoc, multiple comparisons (LSD, least significant difference) between the Age groups (-25, 26 - 35, 36 - 45, 46 $55,56-65,66+$ ) associated with the questions of: (1) How much do you feel afraid when you think about the climate change risks for the whole world? (2) How much do you feel afraid when you think about the climate change risks for the whole world?" Only significant differences are reported) with statistics of mean difference (M.D.), standard error (S.E.), $p$ value and lower and upper bound of $95 \%$ confidence interval (L.B. and U.B.).

\begin{tabular}{|c|c|c|c|c|c|c|}
\hline Questions & Age group & M.D. & S.E. & $p$ & L.B. & U.B. \\
\hline \multirow{6}{*}{ Hope for place where I live } & -25 vs. $46-55$ & 0.34 & 0.16 & 0.03 & -0.66 & -0.03 \\
\hline & $26-35$ vs. $36-45$ & 0.30 & 0.14 & 0.03 & -0.58 & -0.03 \\
\hline & $26-35$ vs. $46-55$ & 0.39 & 0.14 & 0.01 & -0.67 & -0.01 \\
\hline & 36 - 45 vs. $66+$ & 0.36 & 0.16 & 0.02 & 0.06 & 0.67 \\
\hline & $46-55$ vs. $66+$ & 0.45 & 0.16 & 0.00 & 0.14 & 0.76 \\
\hline & $56-65$ vs. $66+$ & 0.33 & 0.17 & 0.05 & 0.00 & 0.65 \\
\hline \multirow[t]{4}{*}{ Fear for the world } & -25 vs. $26-35$ & 0.54 & 0.20 & 0.01 & 0.15 & 0.93 \\
\hline & -25 vs. $56-65$ & 0.71 & 0.21 & 0.00 & 0.31 & 1.12 \\
\hline & -25 vs. $66+$ & 0.60 & 0.21 & 0.01 & 0.18 & 1.02 \\
\hline & $36-45$ vs. $56-65$ & 0.38 & 0.18 & 0.04 & 0.02 & 0.74 \\
\hline
\end{tabular}

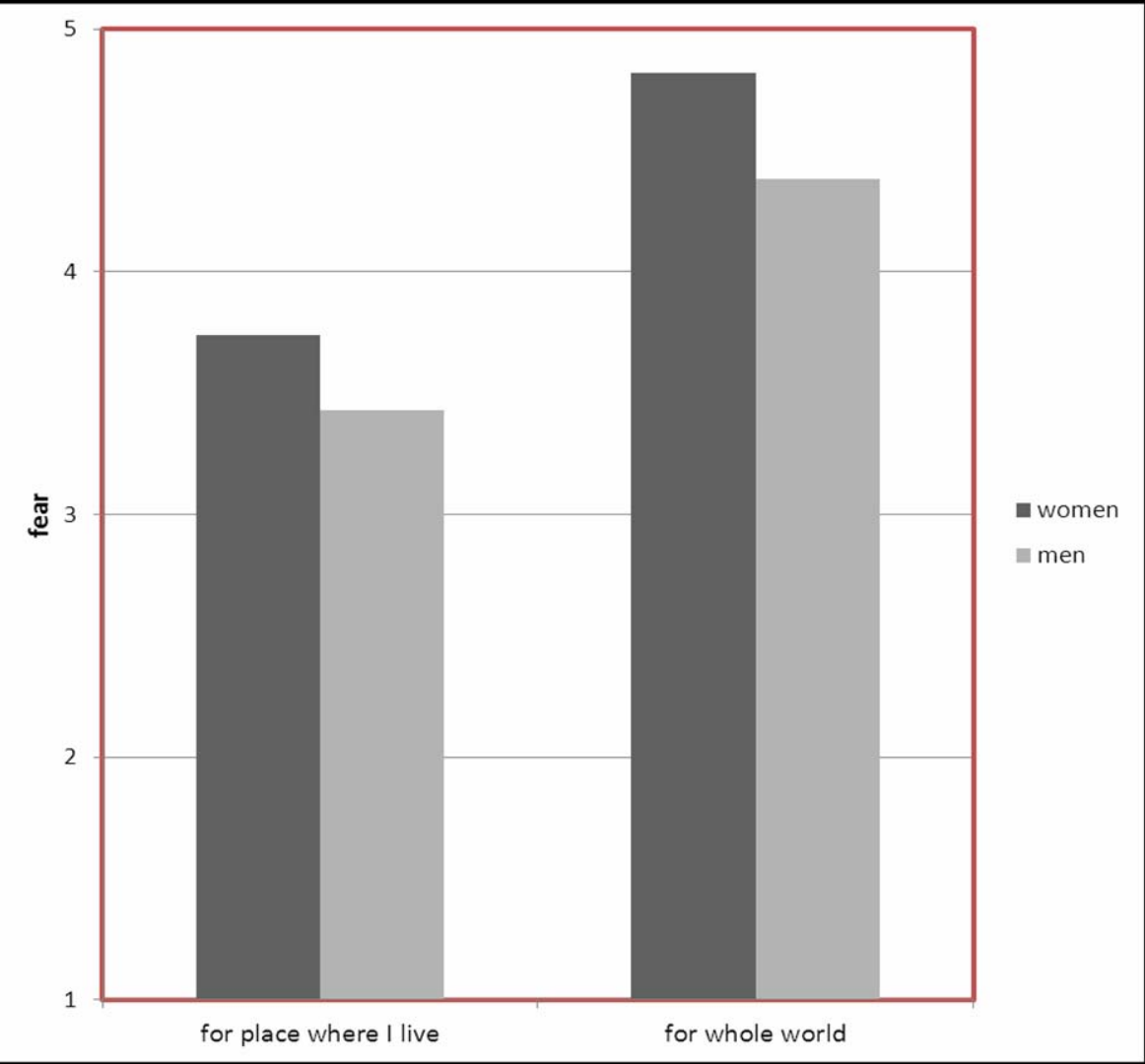

Figure 8. Mean fear in women and men for the place where I live and for the whole world. 


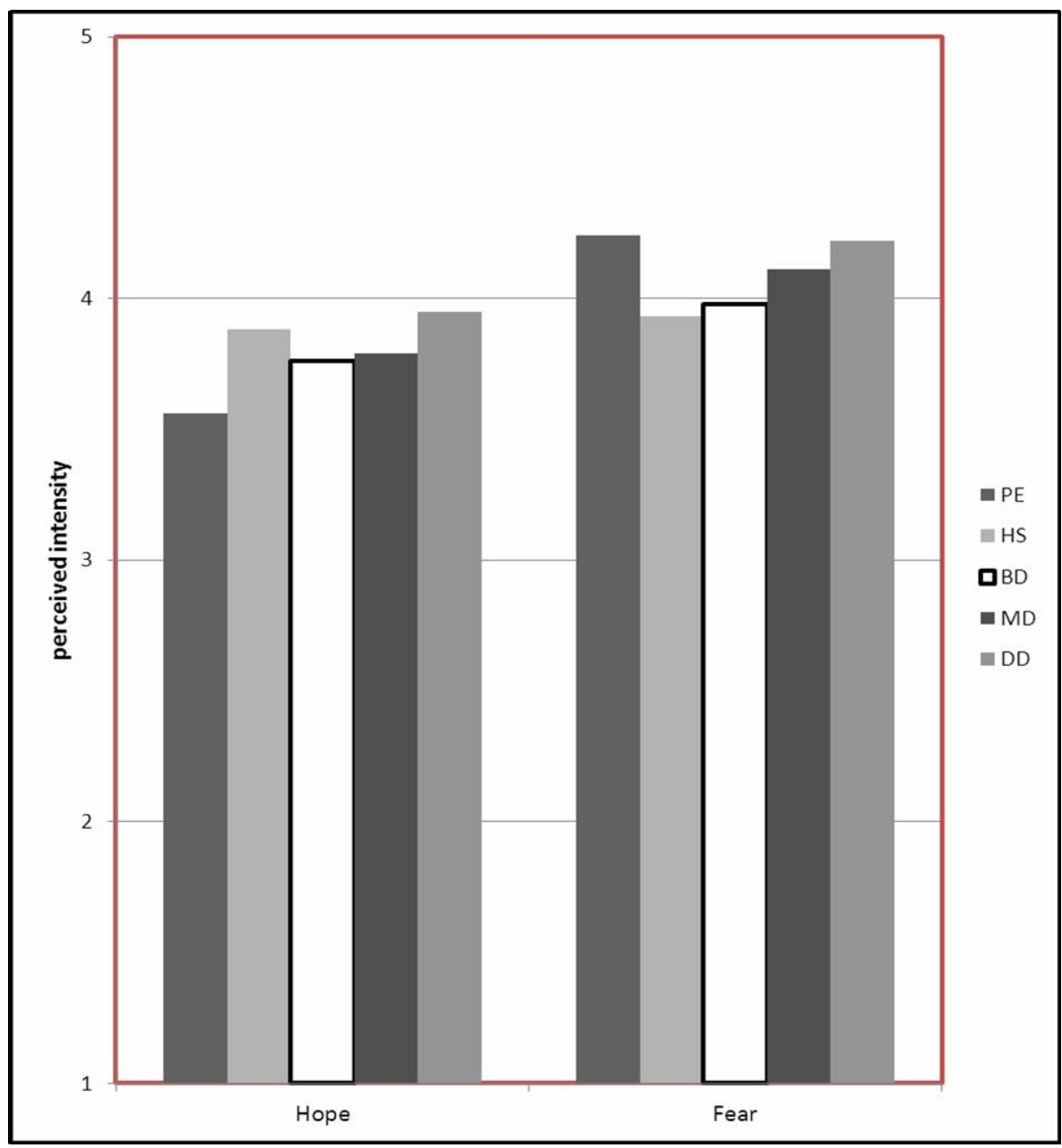

Figure 9. Mean hope and fear in Education groups (Primary Education, PE; High School, HS; Bachelor Degree, BD; Master Degree, MD; Doctoral Degree, DD).

\section{Discussion}

The aim of this article was to investigate effects of different groups of individuals (residents, tourists, experts, decision makers and members of the tourist industry) and demographic variables (gender, age, education across different groups of individuals) on participants' climate change-related concerns, beliefs and emotions.

Concerning the type of group results (Hypothesis 1, see Introduction), Experts (scientists working with climate and environment issues) were shown to be least concerned about and afraid of the global climate change impact. Tourists were shown to be the most concerned and afraid. In line with Sundblad et al. [11] this may indicate that scientists, due to their confidence in their own knowledge, are relatively less emotionally involved and concerned compared to "laypersons"; who are more prone to misjudge the "scientifically uncertain" information $[9,10]$. On the local environmental level, however, Decision Makers (politicians, stakeholders) and the Tourist Industry were shown to react in a similar way to Experts.
The reactions of Residents were similar to those of Tourists. It may be that this highlights a demarcation line between those that know "better" and those that know "poorer"; alluding to [11]. If the Tourist Industry knows "better" or is just lacking in commitment as previously indicated [50], is a question for a future research to investigate.

All participants were shown to be most concerned for children and least for their lifestyle. They also mostly believed that pollution generated in one country harms people all over the world and least that protecting the environment will threaten jobs for people like them. This indicates an environmental value $[23,24,26]$ of socialaltruistic (concern for others) and biospheric (concern for world) orientations in participants, grounding their environmental-related beliefs and concerns [17,60]; because beliefs ("awareness" of the climate change impact) and concerns are supposed to causally relate with value orientations. In the words of Hansla et al. [29, p. 3]: “...a value orientation biases individuals to select and believe 
in information that is congruent with their value orientation and deny value-incongruent information".

However, and in contrast to the above, Residents considered the claims about climate change impact to be more exaggerated than the other four groups did, indicating an egoistic (environmental concerns at a personal level; [20,21]) value orientation in this group of individuals. This is, generally speaking, in contrast with some of the previous findings indicating a positive association between urban residents and environmental issues [31].

Finally, all participants were shown to be most hopeful about neighbouring compared to global environment indicating a type of psychological distance, "escaping affect" [61], in calculating long-term risks, or showing compassion, for the environmental facet. That is, a degree of disengagement from involvement in global compared to local milieu issues was indicated, meaning that neighbouring compared to global threats may be mentally represented differently in our mind.

Concerning the demographic variable results (Hypothesis 2, see Introduction) and as hypothesised [30,31], youngest participants were indicated to be most, and oldest least, concerned about their future as related to climate change impact. Matching their concerns, youngest participants were the most afraid for both types of milieus. The oldest believed that claims that there is a climate change are exaggerated, suggesting an egoistic value orientation in this group of individuals. They were also shown to be most afraid for their neighbouring milieu compared to the whole world, indicating a type of psychological distance ("escaping affect"; [61]).

In line with some previous findings [30,53] women were shown to be generally more concerned about the consequences of climate change compared to men, and they estimated the effects of climate change on health as worse. Men believed that their freedom and jobs would be more threatened by environmental laws and protection than did women, indicating an egoistic and a social-altruistic value orientation $[17,60]$ in men and women respectively. Women were also shown to be more afraid for both local and global arenas, as related to climate change impact. This is in line with some previous research indicating women to be more expressive than men $[62,63]$ and/or embracing environmental-related altruistic values to a higher degree [35]. In sum, and in line with socialization theory $[64,65]$, this type of result indicates that females compared to males are more: “...interdependent, compassionate, nurturing, cooperative, and helpful in caregiving roles" [53, p. 445].

Compared to participants with higher educational levels, the least educated ones were shown to believe that their jobs would be more threatened by environmental laws and protection, and that the claims about climate change are exaggerated. They were also mostly con- cerned about their lifestyle and health. All this indicates an egoistic (environmental concerns at a personal level; $[17,60])$ value orientation in this group of individuals. This is in contrast with some recent findings suggesting that lower class individuals (in this study the lower educated ones; see [66]): “...will act in a more prosocial fashion and do so because of an increased orientation to the needs of others." [67, p. 772; also 68]. In addition, the least educated participants were the least hopeful and the most afraid as related to climate change impact. This may indicate that they are more inclined to misjudge the "scientifically uncertain" information [9-11] and therefore experience fear more intensely than participants with a higher level of education.

\section{Conclusions}

Taken together and in line with the predictions, we have reported significant influences of type of group (residents, tourists, experts, decision makers and members of tourist industry) and demographic variables (gender, age, education across different groups of individuals) on participants' climate-change-related concerns, beliefs and emotions. Alluding to the words of Weber [69, p. 103]: "It should come as no surprise that the governments and citizens of many countries show little concern about climate change and its consequences." we have shown that some individuals do, and some do not, bother about environmental long-term risks such as climate change. This means that these socio-psychological constructs vary with 1) type of social group we belong to; and 2) our gender, age and education; and in turn ground different types of value orientation towards local and global milieus.

Accordingly, when fostering sustainable behaviour, policy support and commitment [70,71] to protect the environment, we have to take into account this diversity in value orientation and environmental risk-related emotion and awareness found in different groups of individuals. As recently pointed out by Patchen [72]: "Programs to combat climate change should be structured so that individuals see their actions as part of a shared social effort",

\section{REFERENCES}

[1] W. Kempton, J. Boster and J. Hartley, "Environmental Values in American Culture," MIT Press, Cambridge, 1995.

[2] L. Saad, "American Sharply Divided on Seriousness of Global Warming," Gallup Poll Monthly, Gallup, Princeton, 2002, pp. 43-48.

[3] P. Schmuck and C. Vlek, "Psychologists Can Do Much to Support Sustainable Development," European Psychologist, Vol. 8, No. 2, 2003, pp. 66-76. 
http://dx.doi.org/10.1027//1016-9040.8.2.66

[4] S. C. Moser and L. Dilling, "Creating a Climate for Change," Cambridge University Press, Cambridge, 2007. http://dx.doi.org/10.1017/CBO9780511535871

[5] M. Bonnes and M. Bonaiuto, "Environmental Psychology: From Spatial-Physical Environment to Sustainable Development," In: R. B. Bechtel and A. Churchman, Eds., Handbook of Environmental Psychology, John Wiley \& Sons, New York, 2002, pp. 28-54.

[6] J. Curry, "Reasoning about Climate Uncertainty," Climatic Change, Vol. 108, No. 4, 2011, pp. 723-732. http://dx.doi.org/10.1007/s10584-011-0180-z

[7] M. van Vugt, "Central, Individual, or Collective Control?" American Behavioral Scientist, Vol. 45, No. 5, 2002, pp. 783-800. http://dx.doi.org/10.1177/0002764202045005004

[8] K. M. Wilson, "Drought, Debate, and Uncertainty: Measuring Reports Knowledge and Ignorance about Climate Change," Public Understanding of Science, Vol. 9, No. 1, 2000, pp. 1-13. http://dx.doi.org/10.1088/0963-6625/9/1/301

[9] N. Stern, "The Economics of Climate Change: The Stern Review," Cambridge University Press, Cambridge, 2006.

[10] G. Böhm and H.-R. Pfister, "Mental Representations of Global Environmental Risks," Research in Social Problems and Public Policy, Vol. 9, 2001, pp. 1-30. http://dx.doi.org/10.1016/S0196-1152(01)80022-3

[11] E.-L. Sundblad, A. Biel and T. Gärling, "Knowledge and Confidence in Knowledge about Climate Change among Experts, Journalists, Politiciants, and Laypersons," Environment and Behavior, Vol. 41, No. 2, 2008, pp. 281-302. http://dx.doi.org/10.1177/0013916508314998

[12] S. Brechin, "Comparative Public Opinion and Knowledge on Global Climate Change and the Kyoto Protocol," Social Policy, Vol. 23, No. 10, 2003, pp. 106-134.

[13] M. Oppenheimer and A. Todorov, "The Psychology of Long-Term Risk," Climatic Change, Vol. 77, No. 1-2, 2006, pp. 1-6. http://dx.doi.org/10.1007/s10584-006-9086-6

[14] W. Viscusi and R. Zeckhauser, "The Perception and Valuation of the Risks of Climate Change," Climatic Change, Vol. 77, No. 1-2, 2006, pp. 151-177. http://dx.doi.org/10.1007/s10584-006-9075-9

[15] S. H. Schwartz, "Universals in the Content and Structure of Values: Theoretical Advances and Empirical Tests in 20 Countries," In: M. Zanna, Ed., Advances in Experimental Psychology, Academic Press, Orlando, 1992, pp. $1-65$.

[16] S. H. Schwartz, "Are There Universal Aspects in the Structure and Contents of Human Values?" Journal of Social Issues, Vol. 50, No. 4, 1994, pp. 19-45. http://dx.doi.org/10.1111/j.1540-4560.1994.tb01196.x

[17] P. C. Stern, "Toward a Coherent Theory of Environmentally Significant Behavior," Journal of Social Issues, Vol. 56, No. 3, 2000, pp. 407-424. http://dx.doi.org/10.1111/0022-4537.00175

[18] P. C. Stern and T. Dietz, "The Value Basis of Environ- mental Concern," Journal of Social Issues, Vol. 50, No. 3, 1994, pp. 65-84.

http://dx.doi.org/10.1111/j.1540-4560.1994.tb02420.x

[19] P. C.Stern, T. Dietz and J. S. Black, "Support for Environmental Protection: The Role of Moral Norms," Population and Environment: Behavioral and Social Issues, Vol. 8, No. 3-4, 1986, pp. 204-222.

[20] P. C. Stern, T. Dietz and L. Kalof, "Value Orientations, Gender, and Environmental Concern," Environment and Behavior, Vol. 25, No. 5, 1993, pp. 322-348. http://dx.doi.org/10.1177/0013916593255002

[21] P. C. Stern, T. Dietz, G. A. Guagnano and L. Kalof, “A Value-Belief-Norm Theory of Support for Social Movements: The Case of Environmentalism," Human Ecology Review, Vol. 6, No. 2, 1999, pp. 81-97.

[22] P. W. Schultz, "Empathizing with Nature: The Effects of Perspective Taking on Concern for Environmental Issues," Journal of Social Issues, Vol. 56, No. 3, 2000, pp. 391-406. http://dx.doi.org/10.1111/0022-4537.00174

[23] P. W. Schultz, "The Structure of Environmental Concern: Concern for Self, Other People, and the Biosphere," Journal of Environmental Psychology, Vol. 21, No. 4, 2001, pp. 1-13.

[24] P. W. Schultz and L. C. Zelezny, "Values and Predictors of Environmental Attitudes: Evidence for Constancy across 14 Countries," Journal of Environmental Psychology, Vol. 19, No. 3, 1999, pp. 255-265. http://dx.doi.org/10.1006/jevp.1999.0129

[25] P. W. Schultz and L. C. Zelezny, "Reframing Environmental Messages to Be Congruent with American Values," Human Ecology Review, Vol. 10, 2003, pp. 126136.

[26] P. W. Schultz, V. V. Gouveis, L. D. Cameron, G. Tanhka, P. Schmuck and M. Franek, "Values and Their Relationship to Environmental Concern and Conservation Behavior," Environment and Behavior, Vol. 36, No. 4, 2005, pp. 457-475.

[27] L. Steg, L. Dreijerink and W. Abrahamse, "Factors Influencing the Acceptability of Energy Policies: A Test of VBN Theory," Journal of Environmental Psychology, Vol. 25, No. 4, 2005, pp. 415-425. http://dx.doi.org/10.1016/j.jenvp.2005.08.003

[28] S. Oreg and T. K. Gerro, "Predicting Proenvioronmental Behavior Cross-Nationally: Values, the Theory of Planned Behavior, and Value-Belief-Norm Theory," Environment and Behavior, Vol. 38, No. 4, 2006, pp. 462-483. http://dx.doi.org/10.1177/0013916505286012

[29] A. Hansla, A. Gamble, A. Juliusson and T. Gärling, "The Relationships between Awareness of Consequences, Environmental Concern, and Value Orientations," Journal of Environmental Psychology, Vol. 28, No. 1, 2008, pp. 1-9. http://dx.doi.org/10.1016/j.jenvp.2007.08.004

[30] A. Olofsson and S. Öhman, "General Beliefs and Environmental Concern: Transantlantic Comparisons," Environment and Behavior, Vol. 38, No. 6, 2006, pp. 768-790. http://dx.doi.org/10.1177/0013916506287388

[31] K. D. Van Liere and R. E. Dunlap, "The Social Bases of Environmental Concerns: A Review of Hypotheses, Ex- 
planations and Empirical Evidence," Public Opinion Quarterly, Vol. 44, No. 2, 1980, pp. 181-197.

http://dx.doi.org/10.1086/268583

[32] T. Dietz, P. C. Stern and G. A. Guagnano, "Social Structural and Social Psychological Bases of Environmental Concern," Environment and Behavior, Vol. 30, No. 4, 1998, pp. 450-471. http://dx.doi.org/10.1177/001391659803000402

[33] K. Boehnke, D. Fuss and M. Rupf, "Values and WellBeing: The Mediating Roles of Worries," In: P. Schmuck and K. M. Sheldon, Eds., Life-Goals and Wellbeing: Towards a Positive Psychology of Human Striving, Hogrefe \& Huber Publishers, Seattle, 2001, pp. 85-101.

[34] R. Garcia-Mira, J. E. Real and J. Romay, "Temporal and Spatial Dimensions in the Perception of Environmental Problems: An Investigation of the Concept of Environmental Hyperopia," International Journal of Psychology, Vol. 40, No. 1, 2005, pp. 5-10. http://dx.doi.org/10.1080/00207590444000078

[35] M. Ojala, "Hope and Worry: Exploring Young People's Values, Emotions, and Behaviour Regarding Global Environmental Problems," Doctoral Dissertation, Örebro University, Örebro, 2007.

[36] S. Gössling and C. M. Hall, "Uncertainties in Predicting Tourist Flows Under Scenarios of Climate Change," Climatic Change, Vol. 79, No. 3-4, 2006, pp. 163-173. http://dx.doi.org/10.1007/s10584-006-9081-y

[37] L. Hein, M. J. Metzeger and A. Moreno, "Potential Impacts of Climate Change on Tourism: A Case Study for Spain," Current Opinion in Environmental Sustainability, Vol. 1, No. 2, 2009, pp. 170-178. http://dx.doi.org/10.1016/j.cosust.2009.10.011

[38] D. Weaver, "Can Sustainable Tourism Survive Climate Change?” Journal of Sustainable Tourism, Vol. 19, No. 1, 2012, pp. 5-15.

[39] J. M. Hamilton, D. J. Maddison and R. S. J. Tol, "Climate Change and International Tourism: A Simulation Study," Global Environmental Change, Vol. 15, No. 3, 2005, pp. 253-266.

http://dx.doi.org/10.1016/j.gloenvcha.2004.12.009

[40] D. Viner, "Tourism and Its Interactions with Climate Change," Journal of Sustainable Tourism, Vol. 14, No. 4, 2006, pp. 317-322.

http://dx.doi.org/10.1080/09669580608669064

[41] S. Gössling and C. Hall, "Tourism and Global Environmental Change: Ecological, Social, Economic and Political Interrelationships," Routledge, London, 2006.

[42] UNWTO "Climate Change and Tourism: Responding to Global Challenges," World Tourism Organixzation and United Nations Environment. World Tourism Organization, Madrid, 2008.

[43] D. Scott, "Why Sustainable Tourism must Address Climate Change," Journal of Sustainable Tourism, Vol. 19, No. 1, 2011, pp. 17-34.

http://dx.doi.org/10.1080/09669582.2010.539694

[44] B. Amelung and D. Viner, "Mediterranean Tourism: Exploring the Future with the Tourism Climatic Index," Journal of Sustainable Tourism, Vol. 14, No. 4, 2006, pp.
349-366. http://dx.doi.org/10.2167/jost549.0

[45] C. E. Hanson, J. P. Palutikof, A. Dlugolecki and C. Giannakopoulos, "Bridging the Gap between Science and the Stakeholder: The Case of Climate Change Research," Climate Research, Vol. 31, No. 1, 2006, pp. 121-133. http://dx.doi.org/10.3354/cr031121

[46] D. Maddison, "In Search of Warmer Climates. The Impact of Climate Change on Flows of British Tourists," Climate Change, Vol. 49, No. 1-2, 2001, pp. 193-208. http://dx.doi.org/10.1023/A:1010742511380

[47] H. M. Wang, F. F. Feng and J. H. Wen, "A Study on Interactions and Impact between Climate Change and Tourism," Proceedings of the 1st International Conference on Sustainable Construction and Risk Management: I and II. Chongqing, 2010, pp. 969-973.

[48] I. Eliasson, G. Olshammar, S. Thorsson, I. Knez, A. Eraydin, B. Gedikli, Ö. Edizel, H. Andrade, E. B. Henriques and R. Machete, "Urban Tourism and Climate Change," Urban-Net Research Anthology, Formas, Stockholm, 2010, pp. 41-47.

[49] D. Scott, C. R. de Freitas and A. Matzarakis, "Adaptation in the Tourism and Recreation Sector," In: G. R. McGregor, I. Burton and K. Ebi, Eds., Biometeorology for Adaptation to Climate Variability and Change, Springer Netherlands, Houten, 2009, pp. 171-194.

[50] D. Scott, P. Peeters and S. Gössling, "Can Tourism Deliver Its 'Aspirational' Greenhouse Gas Emission Reduction Targets?" Journal of Sustainable Tourism, Vol. 18, No. 3, 2010, pp. 393-408.

[51] J. Willms, "Climate Change $=$ Tourism Change? The likely Impacts of Climate Change on Tourism in Germany's North Sea Coast Destinations," In: A. Matzarakis, C. R. De Freitas and D. Scott, Eds., Developments in Tourism Climatology, Freiburg University Press, Freiburg, 2007, pp. 246-253.

[52] P. C. Stern, T. Dietz, L. Kalof and G. A. Guagnano, "Values, Beliefs, and Proenvironmental Action: Attitude Formation toward Emergent Attitude Objects," Journal of Applied Social Psychology, Vol. 25, No. 18, 1995, pp. 16111636.

http://dx.doi.org/10.1111/j.1559-1816.1995.tb02636.x

[53] L. C. Zelezny, P. P. Chua and C. Aldrich, "New Ways of Thinking about Environmentalism: Elaborating Gender Differences in Environmentalism," Journal of Social Issues, Vol. 56, No. 3, 2000, pp. 443-457. http://dx.doi.org/10.1111/0022-4537.00177

[54] B. Gatersleban, L. Steg and C. Vlek, "Measurement and Determinants of Environmentally Significant Consumer Behavior," Environment and Behavior, Vol. 34, No. 3, 2002, pp. 335-362.

http://dx.doi.org/10.1177/0013916502034003004

[55] A. Leiserowitz, "Climate Change Risk Perception and Policy Preferences: The Role of Affect, Imagery, and Values," Climatic Change, Vol. 77, No. 1-2, 2006, pp. 45-72. http://dx.doi.org/10.1007/s10584-006-9059-9

[56] B. McKercher, S. F. H. Pang and B. Prideaux, "Do Gender and Nationality Affect Attitudes towards Tourism and Environment?" International Journal of Tourism Research, 
Vol. 13, No. 3, 2011, pp. 266-300.

[57] M. Ojala, “Adolescents' Worries ABOUT Environmental Risks: Subjective Well-Being, Values, and Existential Dimensions," Journal of Youth Studies, Vol. 8, No. 3, 2005, pp. 331-347.

[58] F. J. McGuigan, "Experimental Psychology: Methods of Research,” Prentice Hall, Inc., Upper Saddle River, 1983.

[59] R. M. Liebert and L. L. Liebert, "Science and Behavior: An Introduction to Methods of Psychological Research," Prentice Hall, Upper Saddle River, 1995.

[60] S. H. Schwartz and J. A. Howard, "A Normative Decision-Making Model of Altruism," In: P. J. Rushton and R. M. Sorrentino, Eds., Altruism and Helping Behavior: Social, Personality, and Developmental Perspectives, Lawrence Erlbaum, Hillsdale, 1981, pp. 189-211.

[61] C. D. Cameron and B. K. Payne, "Escaping Affect: How Motivated Emotion Regulation Creates Insensitivity to Mass Suffering," Journal of Personality and Social PsyChology, Vol. 100, No. 1, 2011, pp. 1-15.

[62] F. Fujita, E. Diener and E. Sandvik, "Gender Differences in Negative Affect and Well-Being: The Case for Emotional Intensity," Journal of Personality and Social Psychology, Vol. 61, No. 3, 1991, pp. 427-434. http://dx.doi.org/10.1037/0022-3514.61.3.427

[63] L. R. Brody, "On Understanding Gender Differences in the Expression of Emotion," In: S. L. Ablon, D. Brown, E. J. Khantzian and J. E. Mack, Eds., Human Feelings: Explorations in Affect Development and Meaning, Analytic Press, Hillsdale, 1993, pp. 87-121.

[64] A. Eagly, "Sex Differences in Social Behavior: A Social Role Interpretation," Lawrence Erlbaum, Hillsdale, 1987.

[65] A. Beutel and M. Marini, "Gender and Values," American Sociological Review, Vol. 60, No. 3, 1995, pp. 436-448. http://dx.doi.org/10.2307/2096423

[66] A. C. Snibbe and H. R. Markus, "You Can't Always Get What You Want: Educational Attainment, Agency, and Choice," Journal of Personality and Social Psychology, Vol. 88, No. 4, 2005, pp. 703-720. http://dx.doi.org/10.1037/0022-3514.88.4.703

[67] P. K. Piff, M. W. Kraus, S. Cote and B. H. Cheng, "Having Less, Giving More: The Influence of Social Class on Prosocial Behavior," Journal of Personality and Social Psychology, Vol. 99, No. 5, 2010, pp. 771-784. http://dx.doi.org/10.1037/a0020092

[68] Y. Ma, C. Wang and S. Han, "Neural Responses to Perceived Pain in Others Predict Real-Life Monetary Donations in Different Socioeconomic Contexts," NeuroImage, Vol. 57, No. 3, 2011, pp. 1273-1280.

http://dx.doi.org/10.1016/j.neuroimage.2011.05.003

[69] E. U. Weber, "Experience-Based and Description-Based Perceptions of Long-Term Risk: Why Global Warming Does Not Scare Us," Climatic Change, Vol. 77, No. 1-2, 2006, pp. 103-120. http://dx.doi.org/10.1007/s10584-006-9060-3

[70] UNCED, “Convention on Biological Diversity," United Nations Conference on Environment and Development Rio de Janeiro, 5 June 1992, p. 79.

[71] S. Menzel and S. Bogeholz, "Values, Beliefs and Norms that Foster Chilean and German Pupils' Commitment to Protect Biodiversity," International Journal of Environmental \& Science Education, Vol. 5, No. 1, 2010, pp. 3149.

[72] M. Patchen, "What Shapes Public Reactions to Climate Change? Overview of Research and Policy Implications," Analyses of Social Issues and Public Policy, Vol. 10, No. 1, 2010, pp. 47-68. 